\title{
MEASUREMENT OF THE QUALITY OF LIFE IN THE REGIONS OF LATVIA
}

Ilze Judrupa ${ }^{1}$, Dr.oec., Assoc.Prof.; Amanda Pipare ${ }^{2}$, BSc

${ }^{1}$ Riga Technical University, Latvia ${ }^{2}$ Riga Technical University, Latvia

\begin{abstract}
Increasing the quality of life is one of the main long-term development goals mentioned in Latvian planning documents. In order to assess whether the goals are achieved, it is necessary to find the optimal solution for quality of life evaluation. The aim of the article is to find the most suitable method for assessing and comparing quality of life in the regions of Latvia. The most popular and easy-to-use method for quality of life evaluation is calculation of the complex index, but the indicators could be normalized according to different methodology. In this paper 7 methods of calculation of indexes were compared and the advantages and disadvantages of each method were determined, as well as the optimal method for calculating the quality of life index at the regional level was chosen. To evaluate quality of life, factors such as financial situation, health, economic activity, education, dwelling, security and environment were used and 10 descriptive indicators were selected. In the assessment of the quality of life in the regions of Latvia, it was concluded that Pieriga and Riga regions have the highest quality of life, but the lowest quality of life is in Latgale region. The most appropriate method for assessing the quality of life is to calculate the Quality of Life (QoL) Index as a percentage of the average, or by using the min-max normalization formula and obtaining index values in the range from 0 to 1 .
\end{abstract}

Key words: quality of life, index, complex measurement system, normalization. JEL code: R11, R12, I31.

\section{Introduction}

The quality of life has become an important research object in many countries of the world. Over time, a number of different methods have been developed to measure quality of life, because quality of life is studied in different sciences from different perspectives. Improving quality of life is also mentioned as one of the main goals of sustainable development in the hierarchically highest planning document of Latvia Sustainable Development Strategy of Latvia until 2030: "Within the scope of the sustainability model, the only possibility of successful response to global challenges is to create such development policy where there is a balance between the necessity to promote the economic growth and to improve the quality of life of each member of the society, the necessity to ensure social unity and safety, as well as the necessity to preserve the ecological environment for future generations." (Cross-Sectoral Coordination Centre, 2010). The National Development Plan of Latvia for 20142020, in its turn, states: "There is inequality between regions and local municipalities in terms of income and economic activity, as well as access to services - which produces pronounced disparities in the quality of life of residents of different regions. This situation encourages the outflow of economically active people from less to more developed territories, which, together with the low level of productivity, further reduce the prospects of growth and available jobs in the less developed territories." (Cross-Sectoral Coordination Centre, 2012). Thus, one of the basic goals of socioeconomic development in Latvia is to increase the quality of life throughout the country. The problem is how to measure the quality of life and assess whether the goal is achieved. A hypothesis of the research is - it is possible to find one optimal method for calculating the Quality of Life (QoL) index and for checking how the set goal is reached in the regions of Latvia. Therefore, the aim of the article is to choose the most suiTable method for assessment and comparison of quality of life in regions of Latvia. In order to achieve this goal, the following tasks were set: to study the existing researches on quality of life and its assessment methods; to select a relatively small number of indicators for assessing the quality of life at the regional level in Latvia; to calculate the QoL index by 7 methods;

\footnotetext{
${ }^{1}$ Corresponding author phone +37129355228, e-mail: ilze.judrupa@rtu.Iv

2 Corresponding author e-mail: pipare.amanda@gmail.com
} 
to choose the most appropriate method for calculating such index. Research methods used were literature overview, analysis, synthesis, monographic or descriptive method, statistical data processing methods, index calculation. Limitations of the research: not all quality of life assessment methods were researched and summarized; only a limited number of indicators were selected for life quality assessment; No population survey was conducted to get subjective indicators; limited statistics at regional level. The scientific novelty of the article is related to the calculation of the QoL index using several approaches.

Life quality research in different fields of science has led to huge discussions among scientists, so the concept of quality of life is recognized as interdisciplinary. The origins of the concept of quality of life are found in ancient philosophy. In European culture it is believed that a happy person is person who has achieved high goals in terms of welfare, education, culture and social status (Tisenkopfs T., Bela B., 2006; Veenhoven R., 2007). The period of industrial development can be considered as the beginning of life quality research from an economic point of view, when issues of poverty and wealth were discussed (Grinfelde A., 2010). A. Smith considered that the welfare of the state was determined by the goods and services it produced. But such production could have also negative side effects (Eisel D. et al., 2014). The development of psychology in the second half of the 1950s helped to include subjective factors in the assessment of quality of life (Veenhoven R., 2000). In the field of sociology, quality of life is perceived as a subjective understanding of well-being, taking into account individual needs. The health sector has played an important role in the development of the concept of quality of life, because in general people live longer, but that does not mean that better (Pinto S. et al., 2017; Susniece A., Jurkauskas A., 2009).

It is necessary to pay attention to the concepts of quality of life and wellbeing, which are interchanged in literature (Glatzer W. et al., 2015). Des Gasper, a professor at the Erasmus University in Rotterdam, explains that the concept of well-being is more widely used at the individual level, but the concept of quality of life - for the general public (Gasper D., 2009). The authors of the article conclude that the definition of quality of life offered by professor R. Cummins of Deakin University is the best for the purpose of the study and will be the basis of this research: "Quality of life is a set of objective and subjective factors that include material well-being, health, productivity, intimacy, security, community and emotional well-being." (Skestere I., 2012). Various definitions of quality of life, as well as different approaches to quality of life research, prove that a universal definition is impossible. However, the World Health Organization's Special Interest Scientists' Group has developed some "conceptualization principles": quality of life is ensured by the ability of a person to meet its needs, as well as the opportunity to further improve living conditions; quality of life is affected by subjective and objective components; quality of life is based on individual needs, individual choice and control; quality of life is multidimensional, influenced by both personal and environmental factors (Schalock R.L. at al., 2002). These approaches to the definition of quality of life were taken as the basis how to select indicators for calculating the QoL index.

\section{Research results and discussion}

Because the quality of life is a multidimensional concept, the most optimal method for its evaluation is the composite index. To develop the QoL index at the regional level of Latvia and to choose the most optimal method for its calculation, several existing quality of life assessments in the world and in Latvia were studied. 
One of the most frequently used indexes for comparison of countries is The Human Development Index, which allows assessing long-term development of nations. A broader range of indicators is included in the OECD Better Life Index, which includes 11 aspects of life quality. The EU statistical centre Eurostat publishes quality of life indicators GDP and beyond, providing statistical information on the quality of life in the EU countries. The publication offers a detailed analysis of the $8+1$ quality of life aspects that can be evaluated statistically. In 2005, the Economist Intelligence Unit developed a specific quality of life index based on a unique methodology - linking research results (surveys) to subjective life satisfaction. The index was calculated including 9 quality of life factors. Latvia's view on the concept of quality of life was created in 2006, when the Strategic Analysis Commission developed the quality of life index for Latvia. Key factors that are assessed in all these QoL indexes are housing, income, work, society, education, environment, civic participation, health, life satisfaction, security, work-life balance (United Nations, 2018; OECD, 2019; Eurostat, 2019; The Economist Intelligence Unit, 2005; Karnitis E. et al., 2006).

In this article, quality of life is not evaluated according to the developed methods, because not all information of the indicators included in these methods is available at the regional level, as well as the survey is not carried out to evaluate subjective factors of the life quality. For the assessment of the quality of life in the regions of Latvia, the Better Life Index, developed by the OECD, will be used as the basis to choose factors, because authors of the article are sure that the index covers the most important aspects of quality of life. The assessment of the quality of life will include factors and indicators that are summarized in the Table 1.

Table 1

Factors and indicators characterizing quality of life

\begin{tabular}{|l|l|}
\hline \multicolumn{1}{|c|}{ Factors } & \multicolumn{1}{c|}{ Indicators } \\
\hline Financial position & $\begin{array}{l}\text { Mean disposable income per household member (EUR/per month) } \\
\text { Severe material deprivation rate among persons ( \%) }\end{array}$ \\
\hline Health & Life expectancy of new-borns (years) \\
\hline Economic activity & Employment level (15-74 years old, \%) \\
\hline Education & $\begin{array}{l}\text { Share of population with higher, vocational or professional secondary education } \\
(15-74 \text { years old, \%) } \\
\text { Participation in adult education ( \%) }\end{array}$ \\
\hline Dwelling & $\begin{array}{l}\text { Dwelling supply with different amenities (water pipe, hot water, sewerage, town } \\
\text { gas, \%) } \\
\text { Average size of dwelling (m²) }\end{array}$ \\
\hline Security & $\begin{array}{l}\text { Share of households identifying crime, violence or vandalism in the area as } \\
\text { problem regarding their household environment ( \%) }\end{array}$ \\
\hline Environment & $\begin{array}{l}\text { Share of households identifying pollution, grime and/or other environmental } \\
\text { problems in the area as problem regarding their household environment (\%) }\end{array}$ \\
\hline
\end{tabular}

The period for data analysis is 2005-2017. If data for this period of time were not available, they were obtained by the linear extrapolation method. Based on generally accepted data normalization and index calculation methods, 7 data normalization methods were selected. The QoL Index was calculated as the arithmetic mean of the normalized indicators (Formula 1).

$$
Q o L=\frac{\sum_{i=1}^{n} X_{n^{\prime r m}}}{n}
$$

Where:

QoL - Quality of Life index; 
$X_{\text {norm }}$ - normalized indicator;

i - sequential number of indicator;

$\mathrm{n}$ - total number of indicators.

To determine which normalization method is the most suiTable for the calculation of the QoL Index, it was assumed that all factors have the same relative weight, or all factors are equally important in the assessment of quality of life.

One of the common methods for index calculation is to calculate it as a percentage of the selected indicator. Table 2 shows the calculation options for this type of indexes.

Table 2

Options of the QoL Index calculation as a percentage of the selected indicator

\begin{tabular}{|c|c|c|c|}
\hline Formula for normalization of indicators & & Results for statistical regions of Latv & \\
\hline $\begin{array}{l}\qquad X_{\text {norm }}=\frac{x}{x_{a v r}} \cdot 100 \% \text { (2) } \\
\text { Where: } \\
\mathrm{X}_{\text {norm }}-\text { normalized indicator; } \\
\mathrm{X} \text { - actual value of the indicator; } \\
\mathrm{X}_{\text {avr }}-\text { average value of the indicator in } \\
\text { the regions. }\end{array}$ & 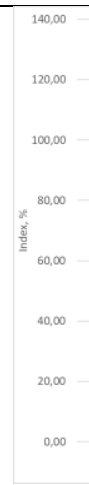 & 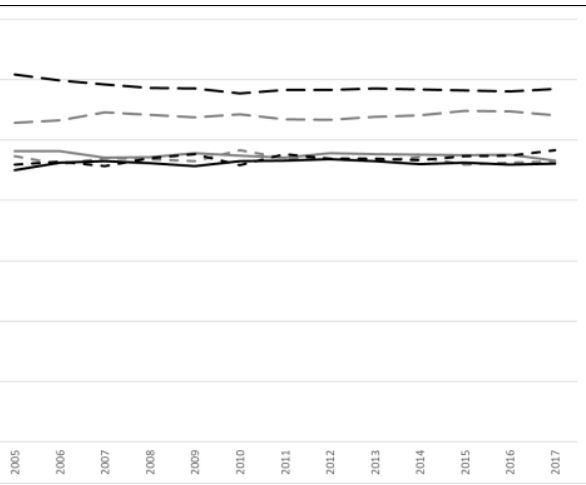 & 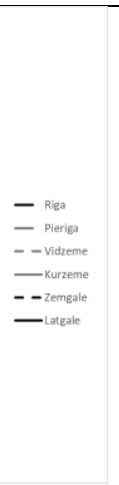 \\
\hline $\begin{array}{l}\qquad X_{\text {norm }}=\frac{x}{x_{\max }} \cdot 100 \% \text { (3) } \\
\text { Where: } \\
\mathrm{X}_{\text {norm }} \text { - normalized indicator; } \\
\mathrm{X} \text { - actual value of the indicator; } \\
\mathrm{X}_{\max }-\text { maximum value of the indicator } \\
\text { among the regions. }\end{array}$ & 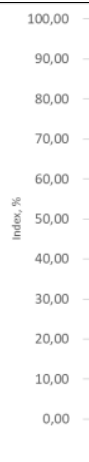 & 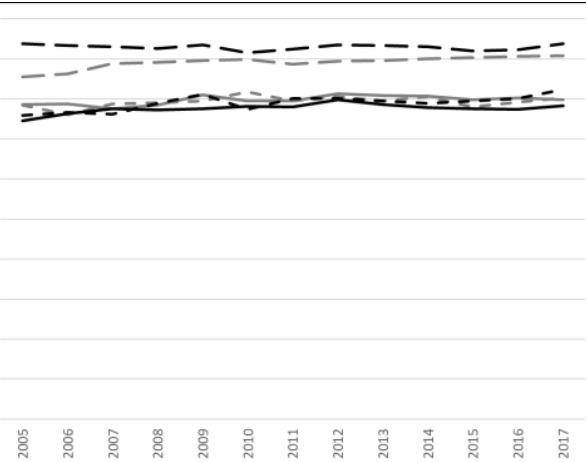 & 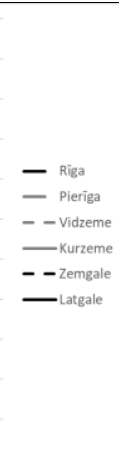 \\
\hline $\begin{array}{l}\qquad X_{\text {norm }}=\frac{x}{x_{\text {Riga }}} \cdot 100 \% \text { (4) } \\
\text { Where: } \\
X_{\text {norm }} \text { - normalized indicator; } \\
X \text { - actual value of the indicator; } \\
X_{\text {Riga }} \text {-value of the indicator in Riga } \\
\text { region. }\end{array}$ & 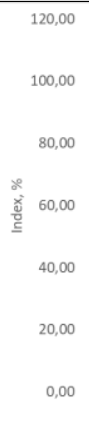 & ニニニ=ー- & $\begin{array}{l}\text { - Riga } \\
\text { - Pieriga } \\
-- \text { Vidzeme } \\
\text { - Kurzeme } \\
- \text { - Zemgale } \\
\text { - Latgale }\end{array}$ \\
\hline
\end{tabular}

Source: author's calculations based on CSB

The QoL Index, calculated according to Formula 1 and using Formula 2 for normalization of indicators, shows the quality of life in each region compared to the average level in Latvia. The average value is taken as $100 \%$, and the actual percentage value for each region may be higher or lower. There are No limits for values of the QoL index. This index shows that the highest quality of life is in Riga region, followed by Pieriga region. Only in these two regions the quality of life is above average. In other regions of Latvia, however, the quality of life is below average and Latgale region takes the last place. The disadvantage of this index is that it is not possible to assess how the quality 
of life has changed over time, because the average level is $100 \%$ throughout the analysed period, regardless of whether it has increased or decreased.

The QoL Index for regions expressed as a percentage of the maximum indicator between regions shows the quality of life in regions compared to the region with the highest score. The maximum value of the index is $100 \%$. This index shows how far each region is from the highest quality of life value. In this case, the maximum score is not the defined target, but the maximum result achieved among regions. It can be seen that the closest to the maximum quality of life is in Riga region, but Latgale region is the most behind.

The QoL Index for regions, expressed as a percentage of a selected target region, allows to compare the quality of life in each region with the selected region. Authors of the article assumed that the quality of life in the Riga region is a target for other regions and it is $100 \%$. It can be seen that from 2014 there is a higher quality of life in Pieriga region than in Riga region. Latgale region lags behind the Riga region most of all. The disadvantage of this index is that it is impossible for the chosen reference region to determine whether the quality of life has changed over time.

None of the methods listed in Table 2 is directly applicable to determine whether the quality of life in the regions has increased and whether the objectives set have been achieved. However, they can be improved by inserting target values as the basis of comparison. It would then be possible to assess whether the regions are approaching or lagging behind the target.

There are also other methods of index calculation described in the literature. One of them is calculation of the index using the min-max normalization of indicators. Such approach is seen, for example, in the calculation of Human Development Index (United Nations, 2018). The other approach is to calculate the index taking into account the standard deviation. This approach is used to calculate the Territory Development Index in Latvia (Cabinet of Ministers, 2014). Examples of calculating these indices in Latvian regions are summarized in Table 3.

Table 3

Options of the QoL Index calculations

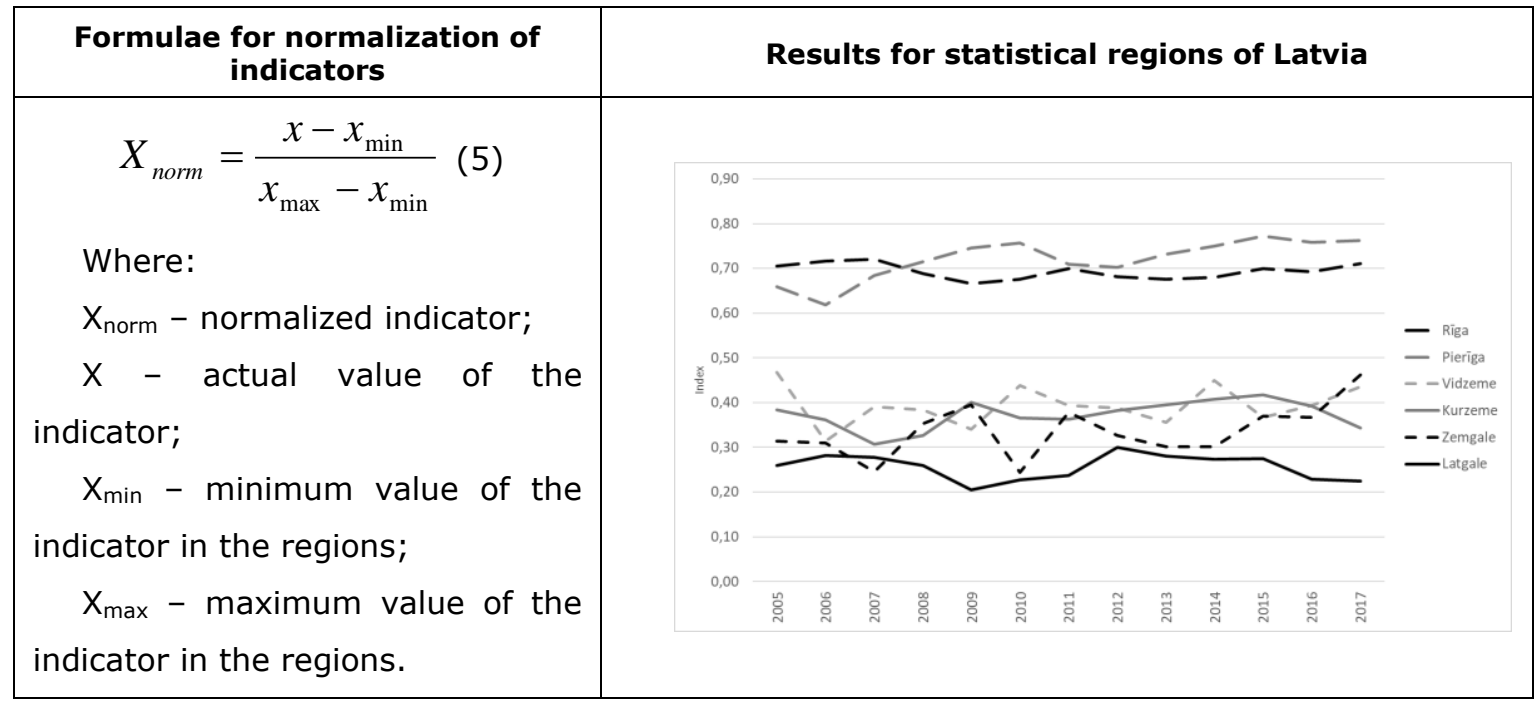




\begin{tabular}{l}
$\begin{array}{c}\text { Formulae for normalization of } \\
\text { indicators }\end{array}$ \\
\hline$X_{n o r m}=\frac{x-x_{a v r}}{S}(6)$ \\
Where: \\
$X_{\text {norm }}-$ normalized indicator; \\
$\quad$ - actual value of the
\end{tabular}

Both index calculations show that since 2008 the Pieriga region has the highest quality of life and the Latgale region has the lowest quality of life during all analysed period. When Formula 5 is used for data normalization, the index limits are from 0 to 1 . No limits are set for index, if Formula 6 is used. The advantage of min-max normalization is that the boundaries of the range, in which the index values will be, can be changed depending on the needs of the researcher. This index is easy to understand and explain.

The last group of indexes includes calculation methods that show changes in time. One of them was used in Latvia to calculate the Quality of Life Index, using Formula 8 (Karnitis E. et al., 2006). The essence of the method is to compare the changes that have occurred in relation to the chosen base period. Methods are shown in Table 4.

Table 4

Options of the QoL Index calculations showing changes in time

\begin{tabular}{|c|c|c|c|}
\hline $\begin{array}{l}\text { Formulae for normalization of } \\
\text { indicators }\end{array}$ & & Results for statistical regions of Latvia & \\
\hline $\begin{array}{l}\qquad X_{\text {norm }}=\frac{x}{x_{0}} \text { (7) } \\
\text { Where: } \\
\mathrm{X}_{\text {norm }}-\text { normalized indicator; } \\
\mathrm{X} \text { - actual value of the indicator; } \\
\mathrm{X}_{0}-\text { base value of the indicator. }\end{array}$ & 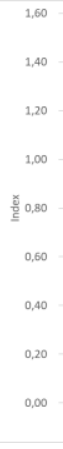 & 总 总 & 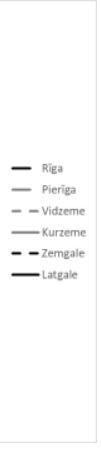 \\
\hline $\begin{array}{l}\qquad X_{n o r m}=\frac{x_{n}}{x_{n-1}} \text { (8) } \\
\text { Where: } \\
\mathrm{X}_{\text {norm }}-\text { normalized indicator; } \\
\mathrm{X}_{\mathrm{n}}-\text { actual value of the indicator; } \\
\mathrm{X}_{\mathrm{n}-1}-\text { previous period value of the } \\
\text { indicator. }\end{array}$ & 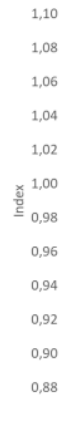 & 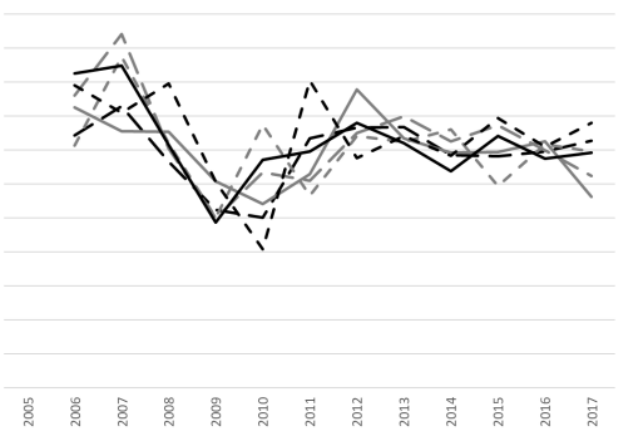 & $\begin{array}{c}\text { Riga } \\
\text { - Pieriga } \\
-- \text { Vidzeme } \\
\text { - Kurzeme } \\
\text { - - Zemgale } \\
\text { - Latgale }\end{array}$ \\
\hline
\end{tabular}


The methods summarized in the Table 4 can be used to assess the development of indicators over time. To calculate the QoL Index using Formula 7 for data normalization, indicators of the year 2005 was chosen as the base values. According to this index, the quality of life in all regions compared to situation in 2005 has increased. The biggest increase was in Zemgale, Pieriga and Latgale regions, but the modest - in Riga region. This could be explained by the relatively high quality of life in Riga region and a lower starting position for other regions of Latvia. In turn, the QoL Index, in which calculation Formula 8 was used, is not easy to understand and it is difficult to compare each region and determine its place among the other regions. From the analysis of this index it can be seen that in 2008-2010 the quality of life in the regions has decreased, but in recent years it has gradually increased.

\section{Conclusions, proposals, recommendations}

1) Quality of life is a multidimensional concept and the most suiTable method for its evaluation is the calculation of the composite index.

2) There is No need for a single definition of quality of life, because the concept is interpreted differently within different sciences, as well as the personal experience and perceptions of quality of life of researchers make definitions different.

3) Depending on the chosen data normalization method, the highest quality of life is in Riga or Pieriga regions. Latgale region is at the last place among statistical regions of Latvia. However, the quality of life has improved in all regions compared to the situation in 2005.

4) The hypothesis has been partially proved, because there is more than one index calculation method, that would be optimal for the calculation of the QoL Index and that could be improved in order to be able to assess the progress of the set goals.

5) To calculate the QoL Index in the regions of Latvia the authors of the article recommend to use one of the following methods: calculation of the index as the percentage of the selected indicator or calculation of the index using min-max normalization. They are the easiest to read and explain to the public, and they represent the situation in the regions of Latvia. However, in order to be able to check the achievement of the goal of improving the quality of life, it would be necessary to set target indicators. They could be placed in those indexes and then it could be possible to find out whether and how much we are lagging behind the target.

6) In order to improve the quality of life assessment, the index developed by authors should be improved by adding subjective indicators and giving importance to the factors. This would be the task of further research.

\section{Bibliography}

1. Cabinet of Ministers of the Republic of Latvia (2014). Regionalas attistibas uzraudzibas un novertesanas kartiba. MK noteikumi Nr.367. Retrieved: https://likumi.Iv/doc.php?id=267737. Access: 06.02.2019.

2. Central Statistical Bureau (CSB) Database (2019). Retrieved: http://www.csb.gov.Iv/dati/statistikasdatubazes-28270.html. Access: 13.02.2019.

3. Cross-sectoral Coordination centre (2010). Sustainable Development Strategy of Latvia until 2030. Retrieved: http://www.pkc.gov.Iv/sites/default/files/images-legacy/LV2030/LIAS_2030_en.pdf. Accessed: 23.01.2019.

4. Cross-sectoral Coordination centre (2012). The National Development Plan of Latvia for 2014-2020. Retrieved: http://www.pkc.gov.Iv/sites/default/files/imageslegacy/NAP2020 \%20dokumenti/NDP2020_English_Final.pdf. Accessed: 23.01.2019.

5. Eisel, D., Rokicka, E., Leaman, J. (2014). Welfare State at Risk. Rising Inequality in Europe. Switzerland: Springer. Retrieved: https://books.google.Iv/books?id=Qe8VAgAAQBAJ\&printsec=frontcover\&hl=|v\&source=gbs_ge_summary_r \&cad $=0 \# v=$ onepage\&q\&f=false. Access: 29.04 .2018 . 
6. Eurostat (2019). Measuring GDP and Beyond. Retrieved: http://ec.europa.eu/eurostat/web/gdp-andbeyond. Access: 02.04.2018.

7. Gasper, D. (2009). Understanding the Diversity of Conceptions of Well-Being and Quality of Life. The Journal of Socio-Economics, Vol 39, pages 351-360. Retrieved: https://www.sciencedirect.com/science/article/abs/pii/S1053535709001474. Access: 15.04.2018.

8. Glatzer, W., Camfield, L., Moller, V., Rojas, M. (2015). Global Handbook of Quality of Life. The Netherlands: Springer. $894 \mathrm{p}$.

9. Grinfelde, A. (2010). Pensionaru dzives kvalitate Latvijas regionos. Summary of dissertation. Jelgava: LLU. $113 \mathrm{p}$.

10. Karnitis, E. et al. (2006). Latvijas iedzivotaju dzives kvalitates indekss. Report of Commission of Strategical Analysis. Cross-sectoral Coordination centre. Retrieved: http://petijumi.mk.gov.Iv/sites/default/files/file/VP_Latv_dzives_kval_indekss.pdf. Access: 23.01.2019.

11. OECD (2019). Better Life Index. Retrieved: http://www.oecdbetterlifeindex.org/\#/11111111111. Access: 02.04.2018.

12. Pinto S., et al. (2017). Comfort, Well-being and Quality of Life: Discussion of the Differences and Similarities among the Concepts. Porto Biomedical Journal, Vol 2, pages 6-12 Retrieved: https://www.sciencedirect.com/science/article/pii/S2444866416301076. Access: 02.04.2018.

13. Schalock R. L., at al. (2002). Conceptualization, Measurement, and Application of Quality of Life for Persons with Intellectual Disabilities: Report of an International Panel of Experts. American Association on Mental Retardation Retrieved:

https://pdfs.semanticscholar.org/e542/e17038b0ab3f3be8d10f1b3744cda0e9906d.pdf. Access: 02.04.2018.

14. Susniene, A., Jurkauskas, A. (2009). The Concepts of Quality of Life and Happiness - Correlation and Differences. Engineering Economic, Vol 3, pages 58 - 66 Retrieved: http://www.inzeko.ktu.It/index.php/EE/article/download/11648/6329. Access: 16.05.2018.

15. Skestere, I. (2012). Petijums par dzives kvalitates izvertejuma metodem un instrumentiem (1.dala). Sabiedribas integracijas fonds. Retrieved: http://www.sif.gov.Iv/nodevumi/nodevumi/4881/petijums_dz_kvalit_1.pdf. Access: 01.03.2018.

16. The Economist Intelligence Unit's Quality-of-Life Index (2005). Economist.com. Retrieved: https://www.economist.com/media/pdf/QUALITY_OF_LIFE.pdf. Access: 02.04.2018.

17. Tisenkopfs, T., Bela, B. (2006). Dzives kvalitate Latvija. Strategiskas analizes komisija. Riga: Apgads "Zinatne". 430 p.

18. United Nations Human Development Report Office (2018). Technical Notes of HDI Calculation. Retrieved: http://hdr.undp.org/sites/default/files/hdr2018_technical_notes.pdf. Access: 04.02.2019.

19. Veenhoven, R. (2007). Quality of Life Research. Bryant, C.D. \& Peck, D.L. '21st Century Sociology, A Reference Handbook' Sage, Thousand Oaks, California USA, Volume 2, chapter 7, pages 54-62. Retrieved: http://www.academia.edu/2975712/Quality-of-Life_Research. Access: 02.04.2018.

20.Veenhoven, R. (2000). The Four Qualities of Life: Ordering Concepts and Measures of the Good Life. Journal of Happiness Studies, Vol 1, pages 1-39. Retrieved:

http://citeseerx.ist.psu.edu/viewdoc/summary?doi=10.1.1.199.9770. Access: 02.04.2018. 